\title{
Role of Plasma Carcinoembryonic Antigen in Diagnosis of Gastrointestinal, Mammary, and Bronchial Carcinoma
}

\author{
D. J. R. LAURENCE, \\ U. STEVENS, \\ R. BETTELHEIM, \\ P. ALEXANDER, E. W. JOHNS, A. MUNRO NEVILLE \\ D. DARCY, C. LEESE, \\ C. TURBERVILLE,
}

British Medical fournal, 1972, 3, 605-609

\section{Summary}

Our studies have confirmed that raised plasma levels of carcinoembryonic antigen (C.E.A.) occur with many but not all malignant tumours, particularly those of the gastrointestinal tract, breast, and bronchus. However, the incidence of raised values may reach $30 \%$ in diseases associated with inflammation or regeneration or both. Consequently, it cannot serve yet as a routine screening test for cancer. Effective surgical therapy results in high plasma C.E.A. levels returning to normal. Subsequent rises appear to develop with tumour recurrence or spread. At present the most useful role for C.E.A. seems to be in monitoring patients during the post-therapeutic followup period. Further basic work is required before C.E.A. can become of routine medical value.

\section{Introduction}

In recent years macromolecules associated with fetal growth have been recognized with increasing frequency in association with a variety of different tumours in adults (Gold and Freedman, 1965; Tee et al., 1965; Yashi et al., 1968; Haakinen and Viikari, 1969; Barnes and Tee, 1970; Buffe et al., 1970; Edynak et al., 1970; Abelev, 1971; Klavins et al., 1971; Trouillas, 1971; Purves and Geddes, 1972) and particular attention has been paid to their possible role in the diagnosis and treatment of neoplasms. They have usually been detected by immunological

\footnotetext{
Royal Marsden Hospital and Chester Beatty Research Institute, London S.W.3

D. J. R. LAURENCE, PH.D., Senior Scientist

U. STEVENS, Junior Technical Officer

R. BETTELHEIM, M.D., Medical Research Assistant

D. DARCY, D.PHIL., Senior Lecturer

C. LEESE, PH.D., Lecturer

C. TURBERVILLE, B.Sc., Scientific Assistant

P. ALEXANDER, D.SC., Professor of Radiobiology

E. W. JOHNS, D.sc., Senior Scientist

A. MUNRO NEVILLE, M.D., M.R.C.PATH., Clinical Scientist
}

methods which have involved raising antisera to them in a heterologous host. For this reason these materials are referred to as fetal antigens, although this does not imply that they are antigenic in the host of origin. The question of terminology is complex and has been discussed by Alexander (1972). To be of practical clinical value such materials will need to pass from the tumour into the body fluids and to decline in quantity with effective therapy. It is hoped that their presence might serve as an indicator of incipient tumour formation and thereby contribute to earlier and more precise diagnosis.

The carcinoembryonic antigen (C.E.A.) is a glycoprotein that appears to fulfil some of the above criteria. C.E.A. was described initially by Gold and Freedman (1965) in primary adenocarcinomas of the colon but not in autologous, uninvolved colonic mucosa, and it was found also in the embryonic liver, pancreas, and gastrointestinal tract during the first two trimesters of pregnancy. More recent investigations have confirmed these observations (Kleinman et al., 1971; Coligan et al., 1972) and also shown very small amounts to be present in normal adult digestive tract tissues (Martin and Martin, 1970). With the development of radioimmunoassays for measuring C.E.A. (Thomson et al., 1969; L.oGerfo et al., 1971; Egan et al., 1972) it was possible to estimate its quantitative occurrence in body fluids in normal subjects and patients with a variety of neoplastic and nonneoplastic disorders.

While originally raised plasma C.E.A. levels were thought to be specific to endodermal tumours (Thomson et al., 1969) further experience with similar (Moore et al., 1971) and different (LoGerfo et al., 1971) reagents has shown that raised C.E.A. values can occur with a wide variety of non-neoplastic disorders and with neoplasms of differing histogenesis, including neuroblastoma (Reynoso et al., 1972). In addition, one of the most recent reports suggests that the C.E.A. level in patients with colonic carcinomas may depend on the extent of spread of the tumour (LoGerfo et al., 1972).

The purpose of this report is to present our attempt to determine the role of plasma C.E.A. assays in the clinical management, diagnosis, and therapeutic monitoring of patients with tumours, particularly of the gastrointestinal tract, breast, and bronchus, and to examine the relation, if any, between the plasma C.E.A. levels and the stage of tumour spread and its degree of structural differentiation. 


\section{Subjects and Methods}

The patients in this investigation were all Caucasian and were drawn principally from the Royal Marsden and St. Bartholomew's Hospitals, London, and the Royal Infirmary, Edinburgh. All were untreated when first seen and their C.E.A. was assayed; this aspect differs from other reports also in this respect. The healthy controls, aged 20 to 60 years, were members of the staff of the Royal Marsden Hospital and the Institute of Cancer Research, London.

A 10-ml blood sample was withdrawn by venepuncture into a tube containing $12 \mathrm{mg}$ tripotassium EDTA. After mixing, the plasma was separated within two hours of collection and stored at $-70^{\circ} \mathrm{C}$ until assayed. A total of 272 duplicate samples were also measured for C.E.A. content by Hoffman LaRoche Inc., New Jersey, using the method of LoGerfo et al. (1971). The samples were shipped by air, packed in solid carbon dioxide in polystyrene foam insulated containers.

The diagnosis of each lesion was confirmed histologically. When false-positive plasma C.E.A. values were detected with benign disorders the pathological material was submitted to further histological examination after sectioning at multiple levels.

A $0.2 \mathrm{ml}$ plasma sample was assayed in duplicate for its content of C.E.A. using the double antibody radioimmunoassay method of Egan et al. (1972) with the exception that a single label-namely, ${ }^{125}$ I C.E.A.-was employed. Goat antiserum, immunospecific for C.E.A. and C.E.A. were kindly supplied by Dr. C. W. Todd, City of Hope National Medical Centre, Duarte, California. C.E.A. was labelled with ${ }^{125} \mathrm{I}$ by the method of Egan et al. (1972). The anti-C.E.A. antiserum was diluted $1: 20$ with phosphate-buffered saline $(0.075 \mathrm{M} \mathrm{NaCl} ; 0.075 \mathrm{M}$ sodium phosphate $\mathrm{pH} 7 \cdot 2$ ). The antiserum was then further diluted in $1: 20$ normal goat serum in phosphate-buffered saline to a final dilution of $1: 1,600$. Then $50 \mu 1$ of the diluted antiserum and $10 \mu \mathrm{l}$ of iodinated C.E.A. (30,000 counts/min; 1-2 ng) were mixed with the sample, together with $10 \mu \mathrm{l}$ of a kanamycin solution to give a final antibiotic concentration of $100 \mu \mathrm{g} / \mathrm{ml}$. An initial trial was made to ascertain that the antibiotic did not displace from the antibody at this concentration.

After an initial count of the mixture this was incubated overnight at $37^{\circ} \mathrm{C}$ and then mixed with $100 \mu l$ of undiluted horse anti-goat IgG titrated and supplied by Dr. Todd's group. After further incubation at $37^{\circ} \mathrm{C}$ for one hour the mixture was held at $4^{\circ} \mathrm{C}$ for five minutes and the supernatant separated by centrifugation and aspirated to waste. The fraction bound was estimated as the ratio of counts before and after incubation.

The standard C.E.A. dilutions were made in phosphatebuffered saline containing $1 \mathrm{mg} / \mathrm{ml}$ rabbit $\mathrm{IgG}$ as recommended by Egan et al. (1972). A comparison with a standard curve using pooled normal plasma as a basis showed that the difference between our scale of C.E.A. and that of the LoGerfo et al. (1971) procedure would, on average, be removed if normal plasma were used in the present assay as the basis for the standard curve (see footnote to Table I).

\section{Results}

Sixty healthy male and female Caucasian subjects aged 20 to 60 years comprised a group of normal controls in whom plasma C.E.A. content was always less than $12.5 \mathrm{ng} / \mathrm{ml}$ by the present assay system. While similar findings are noted in healthy Chinese and Indian subjects the plasma of five out of eight normal Negroes contained $12.5 \mathrm{ng}$ to $30 \mathrm{ng}$ of C.E.A. per ml. Those Negroes with values in excess of $12.5 \mathrm{ng} / \mathrm{ml}$ were not different in age or duration of stay in Great Britain from those whose level was less than $12.5 \mathrm{ng} / \mathrm{ml}$, but all had anti-A activity in their plasma.

The results of estimating preoperatively the plasma C.E.A. level in patients with carcinoma of the gastrointestinal tract, breast, and bronchus are shown in Table I.
TABLB I-Preoperative Plasma C.E.A. Levels in Gastrointestinal, Mammary and Respiratory Disorders

\begin{tabular}{|c|c|c|c|c|c|c|}
\hline \multirow{2}{*}{ Site } & \multirow{2}{*}{ Disorder } & \multicolumn{4}{|c|}{ Plasma C.E.A. (ng/ml) } & \multirow{2}{*}{$\begin{array}{c}\text { Incidence } \\
\text { of Positive } \\
\text { Assays* }\end{array}$} \\
\hline & & $<12.5$ & $<20$ & $<40$ & $>40$ & \\
\hline $\begin{array}{l}\text { Gastro- } \\
\text { intestinal } \\
\text { tract }\end{array}$ & $\begin{array}{l}\text { Carcinoma: } \\
\text { Colon and rectum } \\
\text { Stomach } \\
\text { Pancreas } \\
\text { Other sites } \\
\text { Liver } \\
\text { Polyps: } \\
\text { Colon and rectum } \\
\text { Familial } \\
\text { Inflammatory/reactive: } \\
\text { Ulcerative colitis } \\
\text { Crohn's disease } \\
\text { Diverticulitis } \\
\text { Peptic ulceration } \\
\text { Oesophagitis } \\
\text { Cirrhosis } \\
\text { Other } \\
\text { Haemorrhoids }\end{array}$ & $\begin{array}{r}27 \\
8 \\
1 \\
8 \\
0 \\
9 \\
9 \\
2 \\
22 \\
6 \\
7 \\
14 \\
2 \\
1 \\
7 \\
19\end{array}$ & $\begin{array}{r}18 \\
3 \\
2 \\
6 \\
1 \\
2 \\
0 \\
6 \\
4 \\
1 \\
5 \\
3 \\
0 \\
0 \\
1\end{array}$ & $\begin{array}{r}11 \\
3 \\
1 \\
1 \\
0 \\
0 \\
0 \\
3 \\
0 \\
0 \\
2 \\
0 \\
2 \\
0 \\
0\end{array}$ & $\begin{array}{r}32 \\
1 \\
7 \\
0 \\
2 \\
0 \\
0 \\
0 \\
0 \\
0 \\
0 \\
0 \\
2 \\
0 \\
0\end{array}$ & $\begin{array}{c}61 / 68 \\
7 / 15 \\
10 / 11 \\
7 / 15 \\
3 / 3 \\
\\
2 / 11 \\
0 / 2 \\
9 / 31 \\
4 / 10 \\
1 / 8 \\
7 / 21 \\
3 / 5 \\
4 / 5 \\
0 / 7 \\
1 / 20\end{array}$ \\
\hline Breast & $\begin{array}{l}\text { Carcinoma } \\
\text { Benign tumours: } \\
\text { Fibroadenoma } \\
\text { Duct papilloma } \\
\text { Reactive: } \\
\text { Fibroadenosis } \\
\text { Sclerosing adenosis }\end{array}$ & $\begin{array}{r}42 \\
17 \\
2 \\
41 \\
8\end{array}$ & $\begin{array}{r}18 \\
0 \\
1 \\
1 \\
1\end{array}$ & $\begin{array}{l}5 \\
0 \\
0 \\
2 \\
1\end{array}$ & $\begin{array}{r}14 \\
0 \\
0 \\
0 \\
0\end{array}$ & $\begin{array}{l}37 / 79 \\
0 / 17 \\
1 / 3 \\
3 / 44 \\
2 / 10\end{array}$ \\
\hline $\begin{array}{l}\text { Respiratory } \\
\text { tract }\end{array}$ & $\begin{array}{l}\text { Carcinoma: } \\
\text { Bronchus } \\
\text { Upper respiratory tract } \\
\text { Inflammatory: } \\
\text { Pulmonary tuberculosis } \\
\text { Chronic bronchitis } \\
\text { Cor pulmonale }\end{array}$ & $\begin{array}{r}11 \\
6 \\
13 \\
10 \\
0\end{array}$ & $\begin{array}{r}16 \\
3 \\
5 \\
4 \\
2\end{array}$ & $\begin{array}{l}4 \\
1 \\
3 \\
2 \\
2\end{array}$ & $\begin{array}{l}\mathbf{6} \\
4 \\
0 \\
0 \\
1\end{array}$ & $\begin{array}{c}26 / 37 \\
8 / 14 \\
8 / 21 \\
6 / 16 \\
5 / 5\end{array}$ \\
\hline
\end{tabular}

* Level of $12.5 \mathrm{ng}$ C.E.A./ml plasma is defined as the upper limit of normal and corresponds to $2.5 \mathrm{ng}$ C.E.A./ml by the method of LoGerfo et al. (1971). Similarly,
our values of $20 \mathrm{ng}$ and $40 \mathrm{ng} / \mathrm{ml}$ correspond to $9 \mathrm{ng}$ and $24 \mathrm{ng} / \mathrm{ml}$.

Gastrointestinal System.-Out of 132 patients with carcinomas of the gastrointestinal tract 88 had plasma values in excess of $12.5 \mathrm{ng} / \mathrm{ml}$; the highest incidence, although few in number, was associated with primary pancreatic and hepatocellular carcinomas (Table I). Patients with conditions other than malignant tumours can have raised plasma C.E.A. values (Table I), in particular those with diseases associated with regeneration or mural inflammation or both. However, with the exception of two patients with active cirrhosis, such disorders do not result in levels in excess of $40 \mathrm{ng} / \mathrm{ml}$. If this value is accepted as the upper limit for false-positives, then only $31 \%$ of all overt gastrointestinal carcinomas would be diagnosed by this technique; most of these tumours would already have disseminated at this time (see below). Neither of the two adenomatous polyps associated with a raised C.E.A. level exhibited histological evidence of malignant change. Ulcerative colitis and Crohn's disease are among the commonest disorders associated with plasma C.E.A. values in excess of $12.5 \mathrm{ng} / \mathrm{ml}$ (Table I). The actual plasma C.E.A. level appears to bear no correlation with the activity of either disease as assessed by clinical and histological criteria. The three subjects with ulcerative colitis whose levels exceed $20 \mathrm{ng} / \mathrm{ml}$ had grade II lesions. Extensive clinical and radiological studies failed to produce evidence of neoplastic change. The plasma C.E.A. levels above $12.5 \mathrm{ng} / \mathrm{ml}$ in some patients with peptic ulceration returned to "normal" in the postoperative period. None had histological evidence of carcinomatous ulceration.

Mammary Disorders.-Only $47 \%$ of patients with primary carcinomas of the breast had plasma values over $12.5 \mathrm{ng} / \mathrm{ml}$ (Table I); moreover, the C.E.A. level tended to be lower than that detected with gastrointestinal tumours. The incidence of high C.E.A. levels in benign conditions of the breast was low; none had levels in excess of $40 \mathrm{ng} / \mathrm{ml}$.

Respiratory Disorders.-While a high proportion (66\%) of patients with carcinomas of the bronchus and upper respiratory tract had C.E.A. in excess of $12.5 \mathrm{ng} / \mathrm{ml}$ (Table I), high values were often found in patients with inflammatory chest diseases. Examination of the data from patients with pulmonary infections showed that of the 14 patients falling into the false-positive group 10 smoked cigarettes. None of the healthy control group of subjects who smoked cigarettes had levels in excess of 12.5 
$\mathrm{ng} / \mathrm{ml}$, and of 60 patients with a variety of benign or inflammatory conditions who also smoked cigarettes only 18 had levels over $12.5 \mathrm{ng} / \mathrm{ml}$. The rest had normal values. Thus it may be the combination of chest infection and smoking which is primarily responsible for the raised false-positive levels in such patients.

Miscellaneous.-A variety of neoplastic and non-neoplastic pathological conditions at other sites in the body in which plasma C.E.A. was examined are listed in Table II. With the possible exception of carcinoma of the bladder, where urinary C.E.A. levels can be raised and which is dealt with in detail in

TABLE II-Preoperative or Pretherapeutic Plasma C.E.A. Levels in a Variety of Disorders

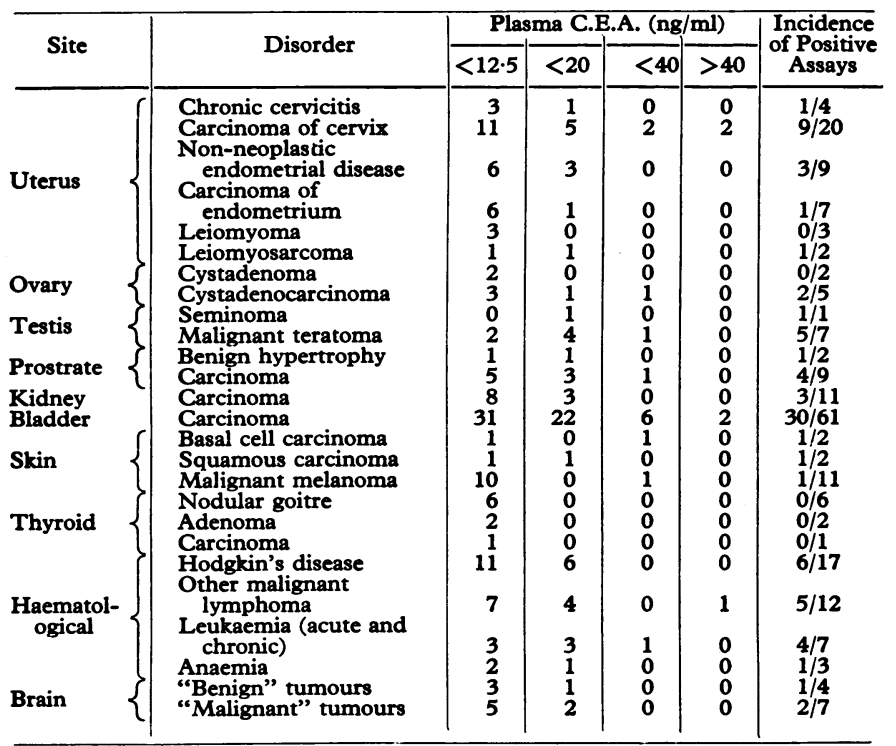

the accompanying paper (Hall et al., 1972), the C.E.A. assay did not appear to be of diagnostic value. It must be stressed, nevertheless, that the numbers are low and that more detailed study may disclose points of interest.

Stage of Tumour Spread and Plasma C.E.A. Levels.-Analysis of the plasma C.E.A. levels as a function of the tumour spread at five principal sites is outlined in Table III. The incidence of raised values and, in addition, the level of plasma C.E.A. increases as the tumours tend to spread further from their site of origin. Only $12 \%$ of early localized tumours (5/29 colonic, $3 / 39$ mammary, and $3 / 24$ bronchial) were associated with values in excess of $40 \mathrm{ng} / \mathrm{ml}$, although in $43 \%$ of the tumours at this stage the levels were above $12.5 \mathrm{ng} / \mathrm{ml}$. By comparison $65 \%$ with local lymph node involvement and $86 \%$ with spread beyond those confines yielded a high plasma C.E.A. result (Table III).

TABLE III-Stage of Spread of Carcinoma of the Gastrointestinal Tract, Breast, and Bronchus and Plasma C.E.A. Levels

\begin{tabular}{|c|c|c|c|c|c|c|}
\hline \multirow{2}{*}{$\begin{array}{c}\text { Site of } \\
\text { Carcinoma }\end{array}$} & \multirow{2}{*}{ Stage } & \multicolumn{4}{|c|}{ Plasma C.E.A. (ng/ml) } & \multirow{2}{*}{$\begin{array}{c}\text { Incidence } \\
\text { of Positive } \\
\text { Assays }\end{array}$} \\
\hline & & $<12.5$ & $<20$ & $<40$ & $>40$ & \\
\hline $\begin{array}{l}\text { Colon and } \\
\text { rectum }\end{array}$ & $\begin{array}{l}\text { Dukes's A* } \\
\text { Dukes's B } \\
\text { Dukes's C } \\
\text { Post-Dukes's C } \\
\text { "Successful therapy" } \\
\text { Local, NO and N+, MO } \\
\text { Metastases (M +) } \\
\text { Local, NO and N+, MO } \\
\text { Metastases (M+) } \\
\text { Local, NO, MO } \\
\text { Local, N+, MO } \\
\text { Metastases (M+) } \\
\text { Local, NO, MO } \\
\text { Local, N +, MO } \\
\text { Metastases (M+) } \\
\text { "Successful therapy" }\end{array}$ & $\begin{array}{r}16 \\
7 \\
4 \\
0 \\
9 \\
6 \\
2 \\
0 \\
1 \\
9 \\
1 \\
1 \\
27 \\
11 \\
4 \\
7\end{array}$ & $\begin{array}{l}6 \\
8 \\
2 \\
2 \\
0 \\
3 \\
0 \\
2 \\
0 \\
9 \\
2 \\
5 \\
9 \\
4 \\
5\end{array}$ & $\begin{array}{l}2 \\
4 \\
1 \\
4 \\
0 \\
1 \\
2 \\
1 \\
0 \\
3 \\
1 \\
0 \\
0 \\
2 \\
3 \\
0\end{array}$ & $\begin{array}{r}5 \\
10 \\
3 \\
14 \\
0 \\
0 \\
1 \\
2 \\
5 \\
3 \\
2 \\
1 \\
3 \\
3 \\
8 \\
0\end{array}$ & $\begin{array}{c}13 / 29 \\
22 / 29 \\
6 / 10 \\
20 / 20 \\
0 / 9 \\
4 / 10 \\
3 / 5 \\
5 / 5 \\
5 / 6 \\
15 / 24 \\
5 / 6 \\
6 / 7 \\
12 / 39 \\
9 / 20 \\
16 / 20 \\
2 / 9\end{array}$ \\
\hline
\end{tabular}
* Dukes (1958).
NO = Local lymph nodes free of tumour deposits. $\mathrm{N}+=$ Local lymph nodes
contain tumour deposits. $M+=$ Tumour spread beyond local lymph nodes. MO $=$ No tumour spread beyond local lymph nodes.
Structural Differentiation of Tumours and Plasma C.E.A.-The incidence of raised plasma C.E.A. levels as a function of structural differentiation of colonic, rectal, and mammary carcinomas is shown in Table IV. The content and release of C.E.A. seems not to be related in any way to the morphological differentiation of the tumours. In addition, each of the principal different histological types of bronchial carcinoma seem equally capable of resulting in raised C.E.A. levels (Table IV).

TABLE IV-Correlation of Histological Type and Plasma C.E.A. Levels

\begin{tabular}{|c|c|c|c|c|c|c|}
\hline \multirow{2}{*}{$\begin{array}{c}\text { Site of } \\
\text { Carcinoma }\end{array}$} & \multirow{2}{*}{ Cell Type or Grade } & \multicolumn{4}{|c|}{ Plasma C.E.A. (ng/ml) } & \multirow{2}{*}{$\begin{array}{c}\text { Incidence } \\
\text { of Positive } \\
\text { Assays }\end{array}$} \\
\hline & & $<12.5$ & $<20$ & $<40$ & $>40$ & \\
\hline $\begin{array}{l}\text { Colon and } \\
\text { rectum }\end{array}$ & $\begin{array}{l}\text { Well differentiated } \\
\text { Moderately well } \\
\text { differentiated } \\
\text { Poorly differentiated }\end{array}$ & $\begin{array}{r}7 \\
13 \\
8\end{array}$ & $\begin{array}{l}6 \\
9 \\
4\end{array}$ & $\begin{array}{l}3 \\
6 \\
3\end{array}$ & $\begin{array}{l}0 \\
5 \\
4\end{array}$ & $\begin{array}{r}9 / 16 \\
20 / 33 \\
11 / 19\end{array}$ \\
\hline Breast* & $\begin{array}{l}\text { I } \\
\text { II } \\
\text { III } \\
\text { Other }\end{array}$ & $\begin{array}{r}3 \\
21 \\
13 \\
3 \\
\end{array}$ & $\begin{array}{l}1 \\
5 \\
4 \\
1\end{array}$ & $\begin{array}{l}0 \\
3 \\
1 \\
0\end{array}$ & $\begin{array}{l}1 \\
2 \\
0 \\
1\end{array}$ & $\begin{array}{c}2 / 5 \\
10 / 31 \\
5 ! 18 \\
3 / 5 \\
\end{array}$ \\
\hline Bronchus & $\begin{array}{l}\text { Oat } \\
\text { Squamous } \\
\text { Adenocarcinoma }\end{array}$ & $\begin{array}{l}2 \\
7 \\
2\end{array}$ & $\begin{array}{l}8 \\
7 \\
1\end{array}$ & $\begin{array}{l}3 \\
1 \\
1\end{array}$ & $\begin{array}{l}1 \\
2 \\
2\end{array}$ & $\begin{array}{c}12 / 14 \\
10 / 17 \\
4 / 6\end{array}$ \\
\hline
\end{tabular}

- According to criteria of Bloom (1950).

Effects of Therapy.-Plasma was obtained preoperatively and several times postoperatively from a total of 87 patients with either gastrointestinal or mammary carcinomas. All cases were considered clinically to have been successfully treated. The preoperative levels of plasma C.E.A. were raised in 43 of the patients; all save three showed a decline postoperatively, normal levels being attained in most by the second to the sixth postoperative day and in all by the 28th postoperative day. Three continued to have high values, but up to the time of writing had no information on the postoperative course of their disease. Of the $\mathbf{4 4}$ patients with normal preoperative values 30 showed no change, and in 14 a transitory rise in the first postoperative week occurred and was followed by a return to normal by the 28th postoperative day.

Tumour Recurrence and/or Spread and Plasma C.E.A. Levels.As many of the patients classified in Table III under the heading Post-Dukes's C or Metastases had developed recurrence of their previously resected colonic or mammary tumours it may be seen that local and distant spread of colonic carcinoma or distant recurrence of mammary tumours is almost always associated with high plasma C.E.A. levels, frequently in excess of $40 \mathrm{ng} / \mathrm{ml}$. Of 18 subjects with no clinical evidence of recurrence of either mammary or colonic carcinomas only two had raised C.E.A. values; their outcome is being followed closely.

Comparison of Two different Methods of Assaying Plasma C.E.A.-Duplicate plasma samples have been assayed by us and by Hoffman LaRoche using the method of LoGerfo et al. (1971). In all, 272 assays were performed and qualitative agreement was observed in $72 \%$ of examples-that is, above or below normal $(12.5 \mathrm{ng} / \mathrm{ml}$ by our method and $2.5 \mathrm{ng} / \mathrm{ml}$ by technique of LoGerfo et al., 1971). In 15\% we found raised levels, while the result of the Hoffman LaRoche method was normal. In the remainder $(14 \%)$ the situation was reversed, with the Hoffman LaRoche technique giving high values and our results being in the normal range. No pattern could be discerned in these discrepancies and they were not obviously related to tumour type or disease state.

\section{Discussion}

The method of Egan et al. (1972), which we used to measure plasma C.E.A., agrees with another, different technique (LoGerfo et al., 1971) if the cut-off for abnormality is set at 12.5 $\mathrm{ng} / \mathrm{ml}$ and $2.5 \mathrm{ng} / \mathrm{ml}$ respectively. The quantitative differences are probably caused by the presence in unextracted plasma of 
interfering background substances. Consequently, the present system, by requiring only a small volume $(0.2 \mathrm{ml})$ of plasma and avoiding the time-consuming extraction and concentration procedures, represents a satisfactory alternative more amenable in time to routine clinical applicability than previous techniques (Thomson et al., 1969; LoGerfo et al., 1971; Moore et al., 1971).

Initially C.E.A. was thought to be an endodermal-specific substance (Gold and Freedman, 1965; Burtin et al., 1971). Further experience using more sensitive methods, however, has resulted in its detection in normal tissues (Martin and Martin, 1970), colonic polyps (Burtin et al., 1972), the plasma of healthy persons and subjects with a variety of tumours of differing histogenesis, and several non-neoplastic disorders (LoGerfo et al., 1971, 1972; Moore et al., 1971; Laurence et al., 1972; Reynoso et ul., 1972; Zamchek et al., 1972). Hence C.E.A. is neither endodermal nor tumour-specific and the differences between its occurrence in normal and neoplastic tissues are quantitative rather than qualitative. It is therefore not surprising that high plasma levels occur in association with reactive hyperplastic and benign neoplastic conditions.

The estimation of plasma C.E.A. appears to have most clinical value in patients with gastrointestinal and bronchial carcinomas and neuroblastomas in this (Tables I, III, and IV) and other series (LoGerfo et al., 1971, 1972; Reynoso et al., 1972; Zamchek et al., 1972). This technique at the present time appears to have little, if any, part to play in the clinical evaluation of tumours of the male and female genitalia and adnexae, skin and brain, or in lymphoreticular neoplasia (Table II). Other tumour-associated antigens have recently been described in Hodgkin's disease (Order et al., 1971) and leukaemia (Viza et al., 1970) but their role in assessing progress and improving diagnosis remains to be evaluated. While the assay of plasma C.E.A. in patients with urothelial carcinoma is of little value, urinary C.E.A. levels are raised in most patients with this disorder. These results are presented in detail in the accompanying communication (Hall et al., 1972).

At the outset of our studies there appeared to be three principal clinical applications of plasma C.E.A. estimation. Firstly, it might serve as a screening procedure for the detection of cancer. Secondly, it might aid in the differential diagnosis of neoplastic disorders and, thirdly, be a means of monitoring the effectiveness of therapy and the development of tumour recurrences.

The present methods of estimating C.E.A. may not warrant its use as a preliminary screening test as they will not detect every subject with cancer and will detect many with non-neoplastic diseases. If one accepts the level of $40 \mathrm{ng} / \mathrm{ml}$ and above as almost pathognomonic of cancer (Tables I and II), then only a minority of tumours would be diagnosed early in their course. If all values in excess of $12.5 \mathrm{ng} / \mathrm{ml}$ are considered abnormal, then this would result in the detection of about $45 \%$ of early primary carcinomas of the colon, rectum, and stomach and about $30 \%$ and $60 \%$ of early mammary and bronchial carcinomas respectively (Table III), while including many patients with non-malignant diseases (Tables I and II). However, we are unable to say that by detecting such a group of subjects in the general or hospital outpatient population, whose plasma C.E.A. levels are raised, and then investigating them in detail lives would not be saved. It may be that a limited trial of its usefulness in a "high-risk" population is still warranted at present.

Neither the cell type nor the degree of structural differentiation of gastrointestinal, mammary, and bronchial carcinomas (Table IV) seems to influence the level of plasma C.E.A., which for most tumours appears to be determined more by the extent of their spread (Table III ; LoGerfo et al., 1972; Zamchek et al., 1972). Disorders such as diverticulitis, peptic ulceration, and ulcerative colitis, which feature prominently in the differential diagnosis of gastrointestinal neoplasia can result in raised C.E.A. levels which, however, do not as a rule exceed $40 \mathrm{ng} / \mathrm{ml}$. In patients with ulcerative colitis and Crohn's disease there does not appear to be any correlation of the C.E.A. level and disease severity. None of these subjects whose C.E.A. level exceed $20 \mathrm{ng} / \mathrm{ml}$ had detectable colonic carcinoma despite diligent searches. Consequently it has a very limited, if any, value in the differential diagnosis of gastrointestinal neoplasia. This conclusion also applies to pulmonary disorders. It would have been valuable to have had a test which could have given some indication of the onset of bronchial neoplasia, particularly in an "at-risk" group such as those who smoke cigarettes. With regard to mammary disorders, while the incidence of falsepositive results is very low, the overall positive rate is such that little reliance can be placed on a negative result. However, it may be premature to dismiss the raised values in some patients with ulcerative colitis, chronic bronchitis, or cirrhosis as being falsepositives. High C.E.A. levels have been observed by others in healthy subjects or those with "non-specific" complaints who subsequently developed carcinomas (LoGerfo et al., 1971). Further sequential studies of these subjects may be warranted.

The most valuable aspect of C.E.A. assay at present may be to monitor therapy and to detect the development of recurrences or tumour spread. We and LoGerfo et al. (1972) found that raised plasma levels decline to normal early in the postoperative period if adequate surgery has been effected. The development of a recurrence or spread of tumours of breast or gastrointestinal origin is almost always associated with a rise in the C.E.A. value. Thus while a negative plasma result does not exclude the presence of tumour it makes the presence of widespread disease highly unlikely. If C.E.A. is assayed preoperatively, one month postoperatively, and at each successive outpatient attendance the method may detect earlier the presence of residual or recurrent disease. Whether any change in the long-term survival or prognosis will result if therapy is instituted at that stage remains to be determined.

Recent experimental data have related the metastasizing ability of some tumours to a loss of their surface glycoprotein into the plasma (Kim and Carruthers, 1972). Consequently it seems important to follow all the subjects of this study with malignant tumours and ascertain if those tumours with high plasma C.E.A. levels pursue a different course and tend to metastasize earlier than those with normal levels.

We would like to express our appreciation to Professor $T$. Symington for his practical help and encouragement in beginning this study, to Dr. C. W. Todd and his colleagues for gifts of the reagents, and to the many clinicians and pathologists who made material available for study. The investigation was supported by the Medical Research Council (Grants 970/656/B and $971 / 817 / B$ ).

\section{References}

Abelev, G. I. (1971). Advances in Cancer Research, 14, 295.

Alexander, P. (1972). Nature, 235, 137.

Barnes, S. J., and Tee, D. E. H. (1970). Protides of the Biological Fluids, ed. H. Peeters, p. 281. Oxford, Pergamon Press.

Bloom, H. J. G. (1950). British fournal of Cancer, 4, 259.

Buffe, D., Rimbault, C., Leinerte, J., Schweisgerth, O., and Burtin, P. (1970). International fournal of Cancer, 5, 75.

Burtin, P., von Kleist, S., and Sabine, M. C. (1971). Cancer Research, 31,

1038. the National Cancer Institute, 48, 25.

Coligan, J. E., Lautenschleger, J. T., Egan, M. L., and Todd, C. W. (1972). Immunochemistry, 9, 377.

Dukes, C. (1958). In Cancer, ed. R. W. Raven, vol. 2, p. 136. London, Butterworth.

Edynak, E. M., Old, L. J., Vrana, M., and Lardis, M. (1970). Proceedings of the American Association for Cancer Research, 11, 22.

Egan, M. L., Lautenschleger, J. T., Coligan, J. E., and Todd, C. W. (1972) Immunochemistry, 9, 289.

Gold, P., and Freedman, S. O. (1965). Fournal of Experimental Medicine, 121, 439.

Haakinen, I., and Viikari, S. (1969). Annals of Surgery, 169, 277.

Hall, R. R., et al. (1972). British Medical fournal, 3, 000

Kim, U., and Carruthers, C. (1972). Proceedings of the American Association for Cancer Research, 13, 69.

Klavins, J. V., Mesa-Tojada, R., and Weiss, M. (1971). Nature, New Biology 234, 153 .

Kleinman, M. S., Harwell, L., and Turner, M. D. (1971). Gut, 12, 1. 
Laurence, D. J. R., et al. (1972). Proceedings of the Royal Society of Medicine.

In Press.
LoGerfo, P., Krupey, J., and Hansen, H. J. (1971). Nero England fournal of Medicine, 285, 138 .

LoGerfo, P., LoGerfo, F., Herter, F., Barker, H. G., and Hansen, H. J. (1972). American fournal of Surgery, 123, 127.

Martin, F., and Martin, M. S. (1970). International fournal of Cancer, 6, 352.

Moore, T. L., Kupchik, H. Z., Marcon, N., and Zamchek, N. (1971). American fournal of Digestive Diseases, 16, 1 .

Order, S. E., Porter, M., and Hellman, S. (1971). New England fournal of Medicine, 285, 471.

Purves, L. R., and Geddes, E. (1972). Lancet, 1, 47.
Reynoso, G., et al. (1972). Fournal of the American Medical Association, 220,

Tee, D. E. H., Wang, M., and Watkins, J. (1965). European fournal of Cancer, 1, 315.

Thomson, D. M. P., Krupey, J., Freedman, S. O., and Gold, P. (1969). (1969). Proceedings of the National Academy of Sciences, 64, 161 . Trouillas, P. (1971). Lancet, 2, 552.

Troullas, P. (1971). Lancet, 2, 552. $\mathrm{T}$ (1970) Nature, 227 1249.

Viza, D., Davies, D. A. L., and Harris, R. (1970) Nature, 227, 1249.

ashi, A., Matsuura, Y., Carpenter, C. M., and Hyde, L. (1968). Fournal of the National Cancer Institute, 40, 663.

Zamchek, N., Moore, T. L., Dhar, P., and Kupchik, H. Z. (1972). New England fournal of Medicine, 286, 83.

\title{
Carcinoembryonic Antigen in the Urine of Patients with Urothelial Carcinoma
}

\author{
R. R. HALL, D. J. R. LAURENCE, \\ D. DARCY, \\ U. STEVENS, \\ R. JAMES, \\ S. ROBERTS, \\ A. MUNRO NEVILLE
}

British Medical fournal, 1972, 3, 609-611

\section{Summary}

Increased amounts of carcinoembryonic antigen (C.E.A.) or C.E.A.-like material are found in the urine of many patients with transitional cell carcinomas of the bladder, including those presumed to be at an early stage of development. It is suggested that measurement of urinary C.E.A. is of clinical diagnostic value in the detection and follow-up of urothelial carcinomas.

\section{Introduction}

In the accompanying paper (Laurence et al., 1972) the radioimmunoassay of the carcinoembryonic antigen (C.E.A.) in plasma is shown to be of clinical value in the diagnosis and follow-up of patients with, in particular, carcinomas of the gastrointestinal tract, bronchus, and breast, although such assays have little or no clinical significance as an initial screening test for cancer in general.

C.E.A. was originally thought to be a specific product of endodermally-derived neoplasms (Gold and Freedman, 1965). Accordingly, in view of the embryological origin of the bladder we have investigated the potential value of urinary C.E.A. measurements for the screening, diagnosis, and follow-up of patients suspected of having urothelial carcinoma.

\section{Subjects and Methods}

The C.E.A. content of urine or plasma, or of both, was measured in patients with urothelial (transitional cell) carcinomas, non-urothelial malignant tumours, and various benign, nonurothelial or renal, diseases. All were inpatients or outpatients of the Royal Marsden Hospital. The urinary C.E.A. levels were also measured in healthy subjects aged 16 to 90 years who were members of the staff of the Royal Marsden Hospital or Institute of Cancer Research, or were inpatients of the Royal Hospital,

\footnotetext{
Royal Marsden Hospital and Chester Beatty Research Institute, London S.W.3

R. R. HALL, F.R.C.S., Vandervell Research Fellow

D. J. R. LAURENCE, PH.D., Senior Scientist

D. DARCY, D.PHIL., Senior Lecturer

U. STEVENS, Junior Technical Officer

R. JAMES, B.SC., Junior Technical Officer

S. ROBERTS, Junior Technical Officer

A. MUNRO NEVILLE, M.D., M.R.C.PATH., Clinical Scientist
}

Chelsea, or the Chelsea Hospital for Women, or who attended a general practitioner's surgery for trivial non-urinary complaints.

Plasma samples were obtained as described previously (Laurence et al., 1972). Urine was collected in $20 \mathrm{ml}$ sterile containers. No special precautions were taken, in that samples were not midstream nor were they taken at any particular time of the day. Each specimen was tested for albumin, glucose, and blood and for infection or bacterial contamination by means of dip-inoculum plates (Oxoid), which were incubated at $37^{\circ} \mathrm{C}$ for 24 hours. If significant infection ( $>100,000$ organisms $/ \mathrm{ml}$ ) was found the organisms were identified. Specimens were stored thereafter at $-70^{\circ} \mathrm{C}$ until assay.

Urine samples in $1 \mathrm{ml}$ aliquots were dialysed using cellulose acetate (Visking 8/32) tubing for three hours against phosphatebuffered saline $\mathrm{pH} 7.2,0.01 \mathrm{M}$ in EDTA. Duplicate $(0.2 \mathrm{ml})$ samples of the undialysable portion were then assayed for their C.E.A. content as described previously (Laurence et al., 1972). The results are expressed as ng of C.E.A. per $\mathrm{ml}$ of urine.

\section{Results}

\section{MALE SUBJECTS}

Analysis of the urinary C.E.A. content of healthy control male subjects yielded a mean level of $14 \mathrm{ng} / \mathrm{ml}$, with a coefficient of variation of $1 \cdot 22$. On this basis $35 \mathrm{ng} / \mathrm{ml}$ was chosen as the upper limit of normal in males; $\mathbf{4 2}$ of the $\mathbf{4 6}$ subjects fell below this level (Table I). None of the four control subjects with raised values had clinical evidence of urinary disease. Examination of the C.E.A. values as a function of age of the control subjects failed to show rising titres with increasing age. Of $\mathbf{3 0}$ males with histologically proved active transitional cell carcinomas of the bladder 20 had urinary C.E.A. levels in excess of $35 \mathrm{ng} / \mathrm{ml}$. Fourteen men who had had previously treated carcinomas of the bladder and who at the time of the present study were judged tumour-free cystoscopically and cytologically all had C.E.A. levels within the normal range. Of the seven patients with benign disorders (including peptic ulceration, ulcerative colitis, and urolithiasis) and the 16 with malignant tumours of other systems (including prostate, testis, renal parenchyma, gastrointestinal tract, and skin) only one with colonic diverticulitis and no evidence of urothelial disease had a raised urinary level of C.E.A. Seven of these 16 patients had plasma levels of C.E.A. between $14 \mathrm{ng}$ and $500 \mathrm{ng} / \mathrm{ml}$.

Examination of the high C.E.A. levels given by carcinoma of the bladder according to the clinical stage of the tumour and its 